2) L. Mullins: J. Appl. Polymer Sci., 2, 257 (1959).

3) 新井洸三, 新海正浩 : 工化誌, 74, 2525 (1971).

4) 深沢義朗：工化誌, 63, 459 (1960).

5) A. Crugnola, M. Pegoraro, F. Danusso, $J$.
Polymer Sci., A-2, 6, 1705 (1968).

6) 野原繁三, 大内重男：高分子化学， 10, 286, 326 (1953).

\title{
MECHANICAL BEHAVIOR OF ELASTOMERS UNDER DEFORMATION
}

\section{Yoshiteru KAZAMA*, Yuzo SUMIDA*, Hiroko OGAWA* and Setsuyo OKAI* (*Industrial Research Laboratories, Kao Soap Co., Ltd., Wakayama 641, Japan)}

Some basic stress-strain behaviors of plasticized PVC have been investigated in terms of the MooneyRivlin equation as a function of temperature, strain-rate and the sort and concentration of plasticizer. From these results, it was found that the pattern of the Mooney-Rivlin isotherm is parabolic below $T_{g}$ and turns out convex above $T_{0}$. A linear isotherm can be observed both around $T_{\theta}$ and well above $T_{0}$.

In order to elucidate this behavior theoretically, the three-elements modle comprising an ideal rubber element $\left(E_{R}\right)$ combined in parallel with a Maxwell unit $\left(E_{H}, \eta ; \eta / E_{H}=\tau_{H}\right)$ was presented as the simplest system manifesting the simultaneous reaction of the entropy tension and the energgy tension thermodynamically not in eguilibruim.

On the basis of the present model, the two constants in the Mooney-Rivlin equation are related with the mechanical parameters as follows: $2 C_{1}=E_{R}, 2 C_{2}=E_{H} / 3$ and $2 C_{2}{ }^{*}=\eta \cdot \dot{\gamma}$. The theoretical MooneyRivlin isotherm in accordance with the experiments reveals the change of the pattern from parabolic to convex with an increasing value of reduced relaxation time, $\tau_{H} \cdot \dot{\gamma}$.

Some experimental verifications of the theory were made in comparison with the data obtained from the capillary-flow and the stress relaxation measurements.

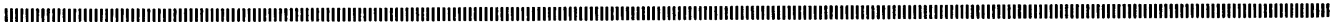

\section{加硫ゴムの大変形挙動に関する研究}

\author{
(昭和50年12月11日 受理)
}

\section{古川 淳二*1 岡本 弘 ${ }^{* 2}$ 稲垣 慎二*2}

要 旨 既に提出した平均鎖によるゴム弾性式は, 加硫ゴムの大変形下における応力一ひずみ挙動をその 伸長，収縮の両曲線に対してよく適合することが分っている。

しかし, 微小変形領域において, 直線からのずれを生じ問題を残している. 種々の現象的観測から，この ずれを加硫ゴムの内部粘性によるものと見なし，三要素粘弾性モデル，及び擬似網目鎖モデルを用いて分子 論的に考察した. この結果, 三要素粘弾性モデルによれば, 理論式中に補正項として誘導されたパラメータ $b$ 及び $b^{\prime}$ は，内部粘性係数と変形速度に関係するものとなり，これらの依存性を実験的に確かめた. また， 補正項 $b$ 及び $b^{\prime}$ は Mooney-Rivlin 式の $C_{2}$ 項と比例的な相関関係があることが認められ， $C_{2}$ 項の分子論的 意味がかなりはっきりした。 これらのことは，高濃度の油展加硫ゴムについてもよく当てはまる．また，伸 長及び収縮曲線に対する補正項 $b$ 差, 及びヒステリシス現象などのチクソトロピカルな性質は粘弾性モデ ルでは説明できない。このため, 分子間力によるからみ合いを二次網目として，その変化を速度論的に解析 し，ヒステリシス現象を説明した.

*1 京都大学工学部合成化学教室（元606 京都市左京区吉田本町）

*2 愛知工業大学応用化学教室（テ470-03 豊田市八草町八千草） 


\section{1. 緒言}

加硫ゴムの一軸に関する応力一ひずみ挙動を説明する ゴム弾性式として，これまでに多くの式が提出されてい るが，微小形領域から大変形領域までの挙動を問題なく 説明し得る式はまだ得られていないのが現状である.

ちなみに, いま, 単位断面積当りの忘力を $f$, 伸長比 を $\alpha$ として網目鎖理論から式(1)が導かれるが1)，この式 は微小変形領域でしか合わない.

$$
f=\nu \boldsymbol{k} T\left(\alpha-1 / \alpha^{2}\right)
$$

$\nu:$ 網目鎖数, $\boldsymbol{k}:$ ボルツマン定数

$T:$ 測定温度

これに対し，伸び切り効果を取り入れたいわゆるラン ジュバン鎖により導かれた James-Guth ${ }^{2)}$, Treloar ${ }^{3)}$ の式 (2)

$$
f=\frac{1}{3} \nu \boldsymbol{k} T \alpha_{m}\left\{\mathfrak{I}^{-1}\left(\alpha / \alpha_{m}\right)-\alpha^{-3 / 2} \mathfrak{L}^{-1}\left(1 / \alpha^{1 / 2} \alpha_{m}\right)\right\}
$$

$\mathfrak{I}^{-1}:$ 逆ランジュバン関数, $\alpha_{m}$ : 最大伸長比 は, 大変形領域での適合性は比較的よいが, 微小変形領 域で問題を残している.

一方，ひずみエネルギー関数をもとにして誘導された Mooney-Rivlin 式 (3) は, $\alpha<3$ の変形領域内での適合 性は認められるものの, 定数項, 特に $C_{2}$ の分子論的意 味について末解決の状態になっている.

$$
\begin{gathered}
f=2\left(C_{1}+C_{2} / \alpha\right)\left(\alpha-1 / \alpha^{2}\right) \\
C_{1}, C_{2}: \text { 定数 }
\end{gathered}
$$

ガウス鎖理論にせよ，ランジュバン鎖理論にせよ，本 質的には比例定理を仮定しているが，実際の網目鎖長に は分布があるはずで伸び切り効果が発現するような大変 形領域で長鎖も短鎖も同じ伸び倍率で伸長を受けること は不合理である。

著者らはこの点を考慮して，平均の伸びをもつ鎖が一 軸方向に $\alpha$ 倍伸ばされるとして式 (4) のようにエントロ ピー変化を求め, それから式(5)を誘導した ${ }^{4)}$.

$$
\begin{aligned}
\Delta S= & \boldsymbol{k}\left\{\ln W\left(\alpha x_{0}, y_{0} / \sqrt{\alpha}, z_{0} / \sqrt{\alpha}\right)\right. \\
& \left.-\ln W\left(x_{0}, y_{0}, z_{0}\right)\right\}
\end{aligned}
$$

$x_{0}, y_{0}, z_{0}$ : 各鎖の両端間距離の平均成分

$$
f=\nu \boldsymbol{k} T\left(\frac{\alpha_{m}}{2} \ln \frac{1+\alpha / \alpha_{m}}{1-\alpha / \alpha_{m}}-\frac{1}{\alpha^{2}}\right)
$$

実際には補正項 $b$ を入れた式(6)がよく適合する.

$$
f=\nu \boldsymbol{k} T F(\alpha)+b
$$

ただ!

$$
F(\alpha)=\left(\frac{\alpha_{m}}{2} \ln \frac{1+\alpha / \alpha_{m}}{1-\alpha / \alpha_{m}}-\frac{1}{\alpha^{2}}\right)
$$

本報では式 (6) に現われる補正項 $b$ の分子論的考察, また，Mooney-Rivlin の $C_{2}$ 項しの対応性，擬似網目モ デルによる加硫ゴムのシステリシスの解釈などにつき述 ベる.

\section{2. 理 論}

式 (6) を種々の純ゴム加硫物に適合すると，得られる 直線はほとんど原点を通らず切片を残す。ヒステリシス 曲線の伸長曲線に適合した場合に得られる切片を $b$ ，収

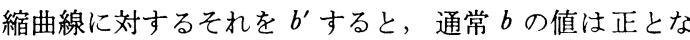
るが， $b^{\prime}$ の值は複雑で，0 または負值をとることが多 い.これらの原点近傍の応力ーひずみ挙動に対して, 三 要素粘弾性モデルと擬似網目モデルを用いて解析した。

\section{1 三要素粘弾性モデル}

図 1 に示す三要素粘弾性モデルを考えて, 加硫ゴム試 料片にかかる応力と $f$ 伸長比 $\alpha$ の関係をヒステリシスル 一プの伸長曲線と収縮曲線に対して，それぞれ次のよう に誘導される。

a. 定速伸長の場合 スプリング1，スプリング 2 の 弾性率をそれぞれ $E_{1}, E_{2}$ とし，ダッシュポット 2 の粘 性係数を $\eta_{2}$, 変形速度を $\dot{\alpha}$ とすれば，三要素モデル全体 にかかる応力 $f$ は式 (7)で表わされる.

$$
\begin{aligned}
f=f_{1}+f_{2}= & E_{1}(\alpha-1)+\eta_{2} \dot{\alpha} \\
& \times\left[1-\exp \left\{-(\alpha-1) / \dot{\alpha} \tau_{2}\right\}\right]
\end{aligned}
$$

$\tau_{2}$ : 要素 2 に対する緩和時間で $\eta_{2} / E_{2}$ に等しい また，ヒステリシスサイクルのもどり点を $\alpha_{c}$ とすれ ば，式(7)と同様にして式 (8)が得られる.

$$
f=E_{1}\left(\alpha_{c}-1\right)+\eta_{2} \boldsymbol{k}\left[1-\exp \left\{-\left(\alpha_{c}-1\right) / \dot{\alpha} \tau_{2}\right\}\right]
$$

b. 定温収縮の場合 収縮曲線に対する応力 $f$ と伸長 比 $\alpha$ の関係は同様にして式(9)のように得られる。

$$
\begin{aligned}
& f=f_{1}+f_{2}=E_{1}(\alpha-1)+\eta_{2} \dot{\alpha} \\
& \times\left[\left[2-\exp \left\{-\left(\alpha_{c}-1\right) / \dot{\alpha} \tau_{2}\right\}\right]\right. \\
& \left.\left.\times \exp -\left(\alpha_{c}-\alpha\right) i \dot{\alpha} \tau_{2}\right\}-1\right] \\
& f=f_{2}=\eta_{2} \dot{\alpha}\left\{2 \exp \left(-\frac{\alpha_{c}-1}{\dot{\alpha} \tau_{2}}\right)\right. \\
& -\exp \left(-\frac{2\left(\alpha_{c}-1\right)}{\dot{\alpha} \tau_{2}}-1\right) \\
& =-\eta_{2} \dot{\alpha}\left\{\exp \left(-\frac{\alpha_{c}-1}{\alpha \tau_{2}}\right)-1\right\}^{2} \leqq 0
\end{aligned}
$$

が得られ，応力 $f$ は $\alpha_{c}>1$ で負值をとるが， $\alpha_{c}=1$ で 0 となる。結局, 三要素モデルにより得られた伸長, 収 


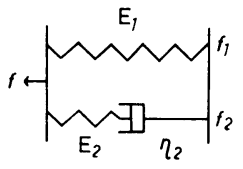

図 1 三要素粘弾性モデル

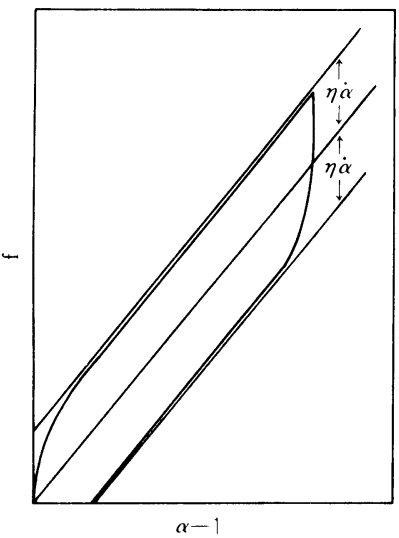

図 2 三要素粘弾性モデルを用いた応力一ひずみ曲 線の模式図

縮曲線に対する式 (7)，(10) を式 (6) と対応させることに より，伸長曲線及び収縮曲線に対する補正項 $b, b^{\prime}$ はそ れぞれ式 (11)，(12) で表わされ，その模式的な応力一ひ ずみ挙動は図 2

$$
\begin{aligned}
& b=\eta_{2} \dot{\alpha} \\
& b^{\prime}=-\eta_{2} \dot{\alpha}\left[\exp \left\{-\left(\alpha_{c}-1\right) / \dot{\alpha} \tau_{2}\right\}-1\right\}^{2} \leqq 0
\end{aligned}
$$

\section{のようになると考えられる}

\section{2 擬似網目鎖モデル}

分子論的粘弾性理論では, 前記の粘性係数 $\eta_{2}$ 及び弾 性率 $E_{2}$ は擬似網目鎖の流動に対する粘性抵抗と弾性率 と見なされる。図 3 に擬似網目モデルを示す。この場 合, 網目は強固な一次結合と弱い二次結合より構成され ていると仮定寸る. 非変形時における網目の変化は式 (13)で表わされる.

$$
d \nu / d t=k(N-\nu)-k^{\prime} \nu=\left(k+k^{\prime}\right)\left(\nu_{0}-\nu\right)=0
$$

$N, \nu ：$ 加硫ゴムの一定容積中にある全セグメント 数及び網目数

$k, k^{\prime}$ : 擬似網目の生成及び消失速度定数

$\nu_{0}$ : 最初に存在していた網目数

一定応力下での網目鎖の変化は式(14)で表わされる. $d \nu / d t=k_{s}(N-\nu)-k_{s}{ }^{\prime} \nu=\left(k_{s}+k_{s}{ }^{\prime}\right)\left(\nu_{s}-\nu\right)$

$k_{s}, k_{s}{ }^{\prime}$ : 一定応力下での網目の生成及び消失速度 $\nu_{s}$ : 一定念力下で最初存在していた網目数 Eyring の粘性理論によれば， $k_{s}$ 及び $k_{s}{ }^{\prime}$ は応力 $f$ とモ

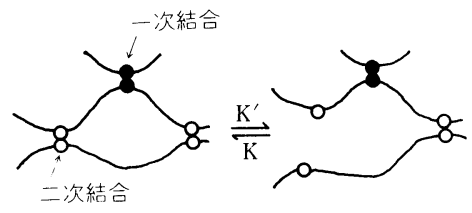

図 3 擬似網目モデル

ル容積 $v$ を用いてつぎのように書くことができる.

$$
\begin{aligned}
& k=k \exp (-f v / 2 \boldsymbol{k} T) \\
& k_{\boldsymbol{s}}{ }^{\prime}=k^{\prime} \exp (f v / 2 \boldsymbol{k} T)
\end{aligned}
$$

モル容積 $v$ は $v=1 / \nu(\mathrm{cc})$ とかけて $f v=\boldsymbol{k} T \boldsymbol{\alpha}$ より， 伸長及び収縮曲線に対してそれぞれ式 (17)，(18) が成立 する。

伸長曲線: $\frac{d \nu}{d \alpha}=\left(\frac{k}{\dot{\alpha}}\right) e^{-B \alpha}(N-\nu)-\left(\frac{k^{\prime}}{\dot{\alpha}}\right) e^{B \alpha}$

収縮曲線： $-\dot{\alpha} \frac{d \nu^{\prime}}{d \alpha}=k e^{-B \alpha}\left(N-\nu^{\prime}\right)-k^{\prime} e^{B \alpha \nu^{\prime}}$

ここで， $\nu^{\prime}$ : 収縮曲線に対する $\nu, B: 1 / 2$ な定数，両

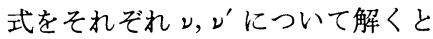

伸長曲線: $\frac{\nu}{N}=A e^{-B \alpha}+\left(\frac{\nu_{0}}{N}-A\right)$

$$
\times \exp \left(-\frac{k+k^{\prime}}{\dot{\alpha}} \alpha\right)
$$

収縮曲線: $\frac{\nu^{\prime}}{N}=A^{\prime} e^{-B \alpha}+\left(\frac{\nu_{0}}{N}-A^{\prime}\right)$

$$
\begin{aligned}
& \times \exp \left(\frac{k+k^{\prime}}{\alpha} \alpha\right) \\
& \text { ここに } \quad A=k /\left(k+k^{\prime}-B \dot{\alpha}\right) \\
& A^{\prime}=k /\left(k+k^{\prime}+B \dot{\alpha}\right) \\
& \nu_{0}: \alpha=0 \text { における }
\end{aligned}
$$

が得られる. 式 (19) と(20)の主要な差異は, 両式の第 2 項の指数のべき符号で, 伸長曲線においては負, 収縮曲

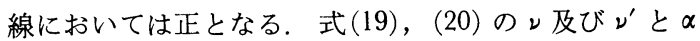
の関係を模式化したグラフを図 4 に示す.

図 4 で伸長曲線においては, 擬似網目レは $\alpha$ とともに 指数関数的に減少するが, 収縮曲線においては ${ }^{\prime}$ は式
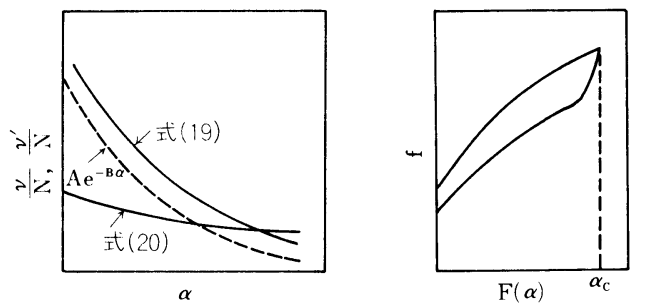

(左)図 4 式(19) と(20)における擬似網目濃度と $\alpha$ の関係 (右)図 5 擬似網目モデルを用いた応力一ひずみ曲線 
(20)の第 2 項が増加関数となっているため, 図のような 曲線となり, もどし点 $\alpha_{c}$ から縮むに従って, 擬似網目 は増加する傾向をたどる. 結局, 全体としての応力一ひ ずみ曲線は図 5 のように表わされ，実際に得られる曲線 をよく説明することができる.

\section{3. 実験 結果}

平均鎖理論によるゴム弾性式 (5) の実際の加硫ゴムに 対する適合性については，NRをはじめ，種々の合成ゴ ムに対するプロットから，ヒステリシス曲線の伸長並び に収縮曲線とも，小変形領域までよく適合するこのを確 認している4). しかし多くの場合，応力とひずみ関数 $F(\alpha)$ のプロットはその直線が原点を通らずに式(6)で表 わされるような切片を残し, 付加項 $b$ の導入が必要とな る. この原点近辺における直線からのずれを粘弾性の問 題と見なしてそれぞれ式(11)及ぶ(12)を導きその実証を 試みた。

\section{1 二，三の加硫ゴムに対する理論式の適用} 式(5)あるいは(6)を用いて，NR, SBR, NBR の純ゴ 厶加硫物についてプロットした結果を図 $6 \sim 7$ に示す. ヒステリシス曲線の伸長, 収縮曲線とも, 大変形領域に 至るまで良い直線性が得られる。しかし，ほとんどの直 線は原点を通らず，伸長曲線に対しては $b$ を，また，収 縮曲線に対しては $b^{\prime}$ なる付加項を必要とし, 式(6)の形 の実験式となることがわかる，一般に $b$ の值は正值を， $b^{\prime}$ の值は 0 または負值を取ることが多い，また， b の值 は極性ゴムほど大きいことが確かめられている4．

\section{$3.2 \nu \boldsymbol{k} \boldsymbol{T} \subset \boldsymbol{C}_{1}$ 項の相烕性}

一般に Mooney-Rivlin 式の $C_{1}$ 項は網目鎖濃度に比例 すると定数されており，(5)のフロントファクターKT $(=\nu k T)$ との相関性を NR の加硫物について確かめた 結果を図 9 に示す。伸長, 収縮曲線とも $C_{1}$ 項と良い相 関関係が得られた，他の合成ゴム類についても同様な結 果が得られている4).

\section{$3.3 b$ 及び $b^{\prime}$ 項之 $C_{2}$ 項の相烕性}

式(6)のプロットから得られる $b$ 及び $b^{\prime}$ （収縮曲線に 対する $b$ の值）と，Mooney-Rivlin プロットから得られ る $C_{2}$ 項の值を $\mathrm{N} \mathrm{R}$ 加硫物について行った結果を図10に 示す。 また, 図11には, ポリブタジェングリコール (PBG)，エチレングリコール (EG), 及び $m$-キシリレン ジイシアナート (MXDI) からワンショット法で合成し た種々のウレタン結合濃度を有するポリウレタンゴムに ついての $b$ 及び $b^{\prime}$ と $C_{2}$ 項のプロット結果を示す。 NR 加硫物については付加項 $b, b^{\prime}$ と $C_{2}$ 項は極めてよい相関 関娛を示す.

架橋形態の全く異なるウレタンゴムにおいても，この 相関はかなりよいと見なせる.

\section{$3.4 b$ 及び $b^{\prime}$ の温度依存性}

$b$ 及び $b^{\prime}$ は式(11)，(12)にみられるように, 粘性係数 $\eta$ に関係した值であると仮想されるため, 種々の加硫ゴ

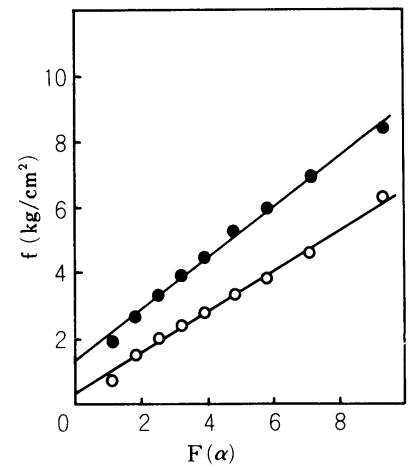

配合 (phr); NR; 100, DCP; 0.5 加硫 ; $160^{\circ} \mathrm{C}, 20 \mathrm{~min}$ 測定温度 ; $23^{\circ} \mathrm{C}$, 引張速度 ; 100 $\mathrm{mm} / \mathrm{min}$ $\alpha_{c} ; 0.95 \alpha b, \alpha_{m} ; 6.0$

；伸長曲線， $\bigcirc$; 収縮曲線

図 $6 \mathrm{NR}$ 加硫物に対する式(6)のプ ロット

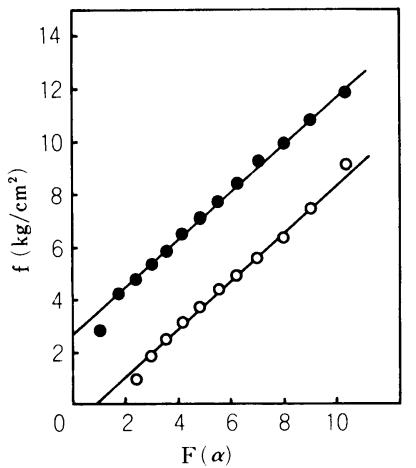

配合 (phr); SBR；100，ステアリ ン酸；1，酸化亜鉛； 5 , DM; $1.0, \mathrm{TT} ; 0.2$, 硫黄 ; 1.5 加硫 $; 160^{\circ} \mathrm{C}, 20 \mathrm{~min}$

測定温度； $23^{\circ} \mathrm{C}$ ，引張速度 ; 100 $\mathrm{mm} / \mathrm{min}$ $\alpha_{c} ; 0.84 \alpha b, a_{m} ; 9.3$

; 伸長曲線, $\bigcirc$; 収縮曲線

図 7 SBR 加硫物に対する式 (6)の プロット

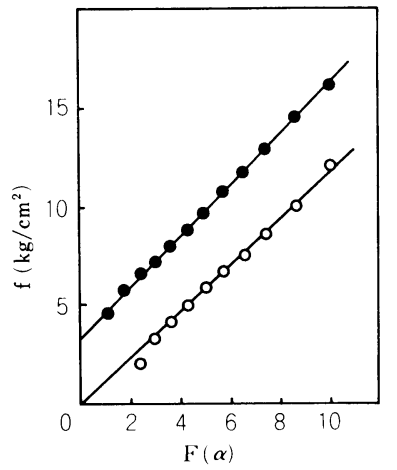

配合(phr); NBR; 100, DCP; 0.25 加硫 ; $160^{\circ} \mathrm{C}, 20 \mathrm{~min}$

測定温度； $23^{\circ} \mathrm{C}$, 引張速度 ; 100 $\mathrm{mm} / \mathrm{min}$ $\alpha_{c} ; 0.90 \alpha b, \alpha_{m} ; 8.4$

; 伸長曲線, $\bigcirc$; 収縮曲線

図 8 NBR 加硫物に対する式(6)の プロット 


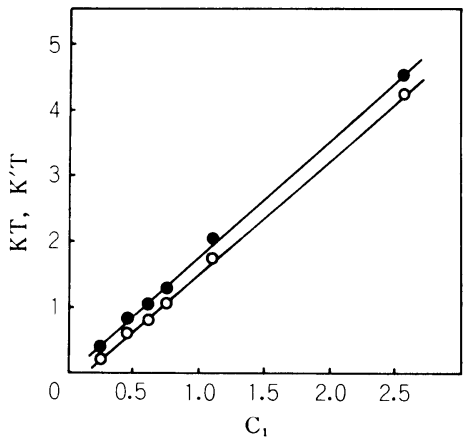

N R 加硫物

; 伸長曲線， $\bigcirc$; 収縮曲線

図 $9 C_{1}$ とフロントファクターの 関係

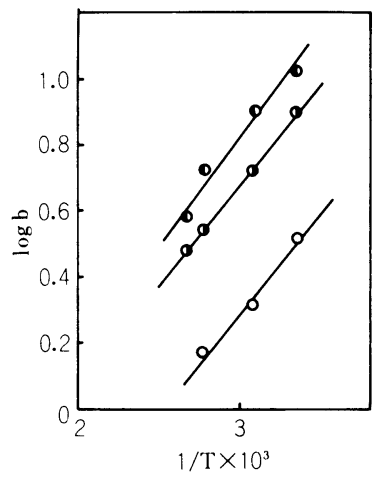

ウレタンゴム

EG/PEG モル比

$\bigcirc ; 0, \bigcirc ; 2, \bigcirc ; 4$

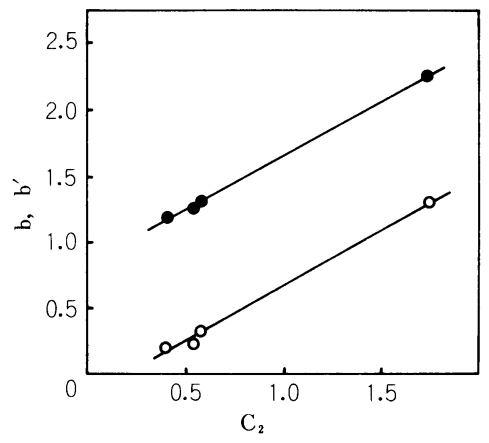

N R加硫物

; 伸長曲線, $\bigcirc$; 収縮曲線

図10 $C_{2}$ と $b, b^{\prime}$ の関係

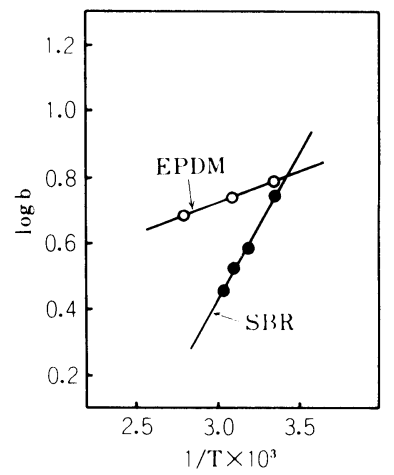

引張速度 $(\mathrm{mm} / \mathrm{min})$

図13 測定温度と $b$ の関係

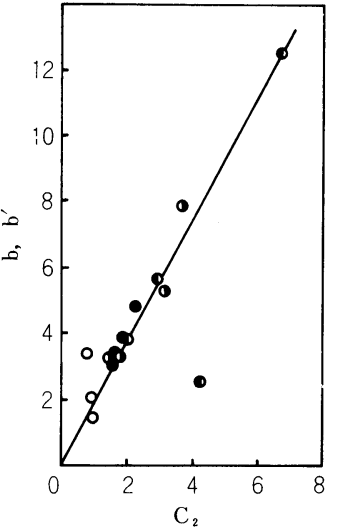

ウレタンゴム

EG/PBG モル比

$\bigcirc ; 0, \bigcirc ; 1, \bigcirc ; 2, \bigcirc ; 4$

図11 $C_{2}$ と $b, b^{\prime}$ の関係

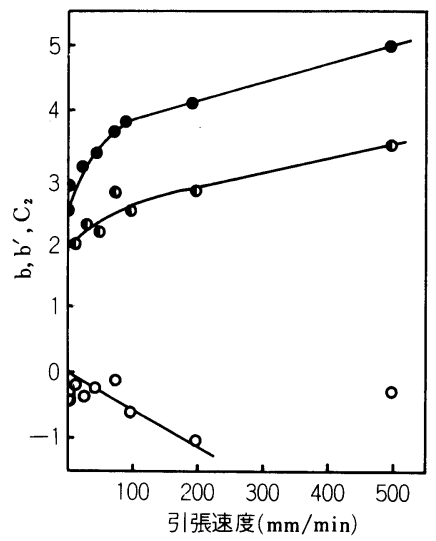

$; b, \quad \bigcirc ; b^{\prime}, \quad \bigcirc ; C_{2}$

図14 $b, b^{\prime}$ および $C_{2}$ の引張速度依 存性

図12 測定温度と $b$ の関係

ムについて測定温度依存性をみた。図12には前記のポリ ウレタンゴムについての結果を，また,図13には EPDM, SBR 加硫物についての結果を示す. これらの測定結果 から流動の活性化エネルギーを求めるとポリウレタンゴ ムについてはウレタン給合濃度により変化するが大体 $2.7 \sim 3.0 \mathrm{kcal} / \mathrm{mol}$ ，また EPDM 加硫物については 0.9 $\mathrm{kcal} / \mathrm{mol} \mathrm{SBR}$ 加硫物については $4.0 \mathrm{kcal} / \mathrm{mol}$ となり, 付加項 $b$ 及び $b^{\prime}$ の分子論的意味は内部粘性に基づくも のとほぼ推察される。

\section{$3.5 b$ 及ひ $b^{\prime}$ の変形速度依存性}

式(11)，(12)より， $b, b^{\prime}$ は変形速度 $\dot{\alpha}$ に依存するパ ラメータへ解釈させるため, 伸長, 収縮速度を $4 \mathrm{~mm} /$ $\min \sim 500 \mathrm{~mm} / \mathrm{min}$ に変化させて測定した SBR 加硫物
に対する結果を図14に示す，同時に Mooney-Rivlin プ ロットから得られる $C_{2}$ 項の $\dot{\alpha}$ 依存性についても検討し た.

伸長曲線に対する $b$ の $\dot{\alpha}$ 依存性は $\dot{\alpha}$ と共に増大する. 曲線の形は同一の試料について得られた $C_{2}$ 項の $\dot{\alpha}$ 依存 性のそれと似ており $\dot{\alpha}=100 \mathrm{~mm} / \mathrm{min}$ 付近に変曲点が あるような形となっている，一方，収縮曲線に対する $b^{\prime}$ の $\dot{\alpha}$ 依存性は $\dot{\alpha}$ が $200 \mathrm{~mm} / \mathrm{min}$ の範囲内では $\dot{\alpha}$ と共 に減少を示し， $b, b^{\prime}$ とも式(11)，(12)の関係を比較的よ く表現しているようにみえる.

\section{6 油展 SBR 加硫物に対する結果}

これまでの結果はすべて純ゴム加硫物に対するもので あったが，プロセス油をゴムに添加した場合の挙動をみ 
るために，SBR にプロセス油を 5 〜 70 部種々の割合で 加えた加硫物について検討した.

a. 理論式の適合性 油展 SBR 加硫物に対する式 (5)あるいは(6)の適用結果の代表例を図15に示す。理論 式は高濃度油展加硫物についても，高伸長領域まで，よ く適合している.

b. 油展量と各パラメータの関係 図16 18にプロセ ス油添加量と $\nu \boldsymbol{k} T, b$ 及び $b^{\prime}, C_{1}$ 及び $C_{2}$ 項の関係を示 した. 油展量と共に $b, b^{\prime}, C_{1}, C_{2}$ はほぼ直線的に減少す る. 油展 $\mathrm{SBR}$ 加硫物の $C_{2}$ 項は一般に $C_{1}$ 項より大き い.

c. $\boldsymbol{C}_{1}$ 項とフロントフ○クターの関係 油展 SBR の 加硫物に対する $C_{1}$ 項と $\nu k T$ の関倸を図19k示す． $C_{1}$

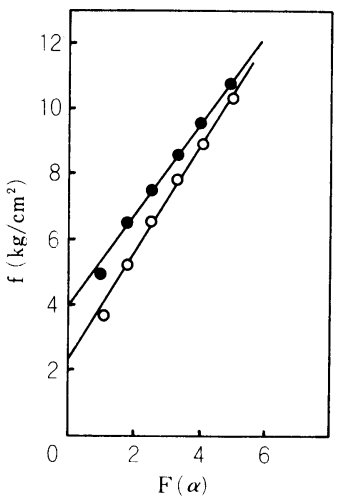

配合 (phr), SBR; 100，ステアリン酸；1，酸化 亜鉛；5，DM；2，硫黄；2，油；5

加 $; 160^{\circ} \mathrm{C}, 20 \mathrm{~min}$

測定温度 ; $23^{\circ} \mathrm{C}$, 引張速度 ; $100 \mathrm{~mm} / \mathrm{min}$

$\alpha_{c} ; 0.8 \alpha b, \alpha_{m} ; 5.1$

；伸長曲線，○；収縮曲線

図15 油展 SBR 加硫物に対する式(6)のプロット
項と $\nu k T$ は SBR の純ゴム加硫物におけるものと同様良 い相関関係を示す.

d. $\boldsymbol{C}_{2}$ 項と $\boldsymbol{b}$ 及び $\boldsymbol{b}^{\prime}$ の関係 罒20に両者の值をプロ ットした結果を示す。ヒステリシスの伸長，収縮曲線と もその傾きは異なるが良い直線関係が得られた。

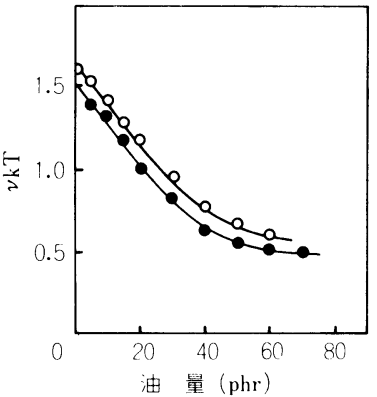

SBR

?; 伸長曲線, $\bigcirc$; 収縮曲線 図16 油量と $\nu k T$ の関係

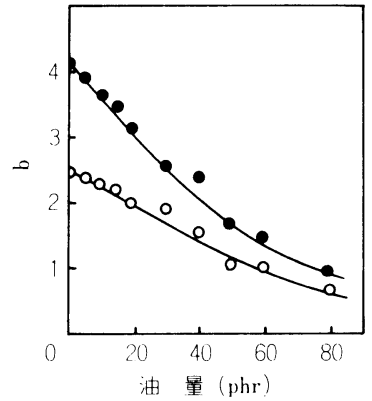

SBR

D; 伸長曲線, $\bigcirc$; 収縮曲線 図17 油量と $b$ の関倸

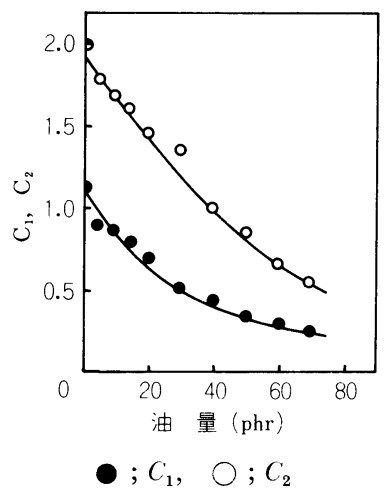

図18 $C_{1}, C_{2}$ と油量の関係 SBR

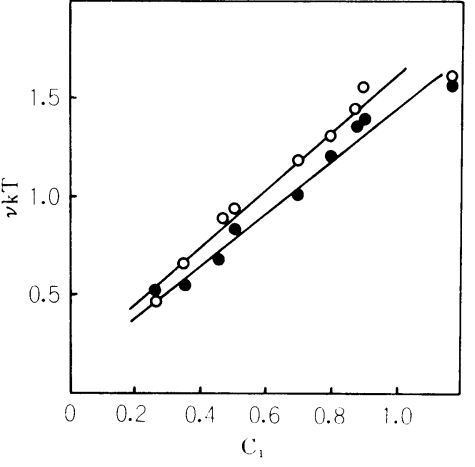

; 伸長曲線, $U$; 収縮曲線

図19 油展 SBR 加硫物の $C_{1}$ と $\nu k T$ の関係

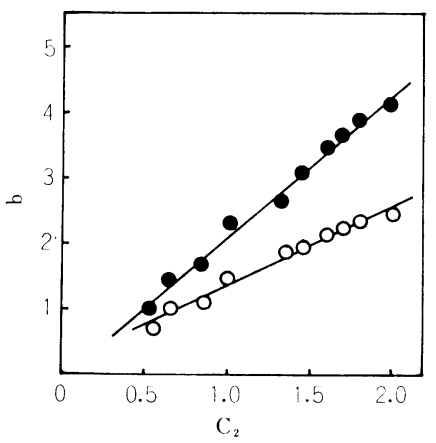

○; 伸長曲線, $\bigcirc$; 収縮曲線 四20 油展 $\mathrm{SBR}$ 加硫物の $C_{2}$ と $b$ の)関係 


\section{4. ま と め}

比例定理の不合理性を排除して, 均一張力原理に基ゔ き平均鎖を仮定して，そのエントロピー変化より張力一 のずみ関係を表わすゴム弾性を誘導した。 この理論式に よると純ゴム加硫物や高濃度油展に対して, 伸び切り領 域まで，その伸長，収縮曲線の変形挙動をよく説明でき る.しかし，実験的には大部分の直線は原点を通らず に, $b$ 及び $b^{\prime}$ で表わす補正項を必要とし, 式 (6) の形が 合理的なものとなった. 理論式 $\nu k T$ のは純ゴム加硫物, 油展加硫物とも加硫剂濃度に比例し, かつ MooneyRivlin プロットで得られる $C_{1}$ 項と直線的な比例関係が 認められた。 また, 種々の加硫ゴム及び油展 SBR 加硫 物などについて補正項 $b$ および $b^{\prime}$ と $C_{2}$ 項の比例的な 相関関係が見出された. この補正項はヒステリシスと関 係があり，現象的にみても油展により低下し，ニトリル ゴム5), ウレタンゴむなどの極性ゴムで大きな值を示 し, かつ, 活性化エネルギーが $1 \sim 4 \mathrm{kcal} / \mathrm{mol}$ と低い值 を示すことなどから，ゴムの内部粘性に基ゔくものと推 察される.このため, 三要素モデルにより補正項を分子 論的に考察した結果, 伸長曲線の $b$ に対しては $\dot{\alpha} \eta に$, 収縮曲線に対しては一 $\dot{\alpha} \eta$ に比例したものとなり，実験 的にも認された。しかし，実際には，伸長曲線と収縮曲 線の補正項 $b$ 及び $b^{\prime}$ は異なり，また，ヒステリシスが 第 2 サイクル以後, 著しく小さくなることなどのチクソ トロピカルな性質はこの粘弾性モデルでは説明できな い.そこで，分子間力にたるからみ合いを二次網目とし てその変化を考える所の擬似網目理論により解析を試み た. その結果, 網目濃度は伸長曲線に対しては $\alpha$ に関し ては減少関数となるが, 収縮曲線に対しては増加関数と なり，実際のヒスヒリシス曲線の姿をよく表現できる.

Mooney-Rivlin 式の $C_{2}$ 項の分子論的意味について は，末だ解明されていないが，補正項 $b$ の諸条件因子の 依存性の検討の際に同時に観測される $C_{2}$ 項のそれ，す なわち, 変形速度, 測定温度, ヒステリシスサイクル, 可塑剤あるいは膨潤凪などの影響からみて $C_{2}$ 項はゴム
の内部粘性に関係したものであることが推察される.

これは $C_{2}$ 項が実験的にも多種の加硫ゴム, 加硫形態 及び油展ゴム加硫物に対して，たまたま補正項の $b$ 及び $b^{\prime}$ 值と比例的な相関関係があることが見出された事実と 相まって興味樑い.

元来, Mooney-Rivlin 式を展開すると

$$
f=2 C_{1}\left(a-1 / \alpha^{2}\right)+2 C_{2} / \alpha\left(\alpha-/ \alpha^{2}\right)
$$

で表わされるが, 著者らの擬似網目モデルによれば, 試 料を一軸伸長した場合, 変形の前後で単位断面積当りの 強固なる一次網目鎖濃度の変化はないと仮定でき，した がって，展開式の第 1 項，すなわち， $C_{1}$ 項部分は面積補 正をする必要性はなく， $2 C_{1}=\nu k T$ とすれば，網目理 論式と同一形となる。しかし, 分子間力によるからみ合 いを二次網目と見なして，伸長変形によりこの二次網目 がスリップを起こすものと仮定すれば，単位断面当りの 二次網目濃度は変化を生じるので, 面積補正の必要を生 じる.このため, 展開式の第 2 項, すなわち, $C_{2}$ 項部分 は，もしそれがゴムの内部粘性に関する因子と仮定すれ ば，伸長比 $\alpha$ のき，その断面は $1 / \alpha$ となり，第 2 項の $1 / \alpha$ は面積補正倸数と見なせる. 実験的にも， $C_{2}$ 項の時 間, 温度依存性が確認されており, 内部粘性的西素が極 めて強い. かかる見地よりすれば，変形によりスリップ を生じた二次網目鎖は $C_{1}$ 項へ流入することが予想され， $C_{2}$ 項の変動とともに $C_{1}$ 項の変動も生ずることになる.

\section{文献}

1) W. Kuhn, Kolloid Z., 68, 2 (1934), 76, 258 (1936); 87, 3 (1939); Naturwiss., 24, 346 (1936)

P. Flory, J. Rehner, J. Chem. Phys., 11, 521 (1943)

2) H. James, E. Guth, J. Chem. Phys., 11, 455 (1943); 15, 669 (1947)

3) R. L. Treloar, Trans. Roy. Soc., A241, 375 (1948)

4) J. Furukawa, H. Okamoto, S. Inagaki, IRC-74 in Munich (1974); Kautschuk Gummi, Kunststoffe., in Press; 日ゴム協誌，投稿中

5）古川淳二, 岡本 弘, 稲垣慎二, 日ゴム協誌投 稿中

\section{RUBBER ELASTICITY AT LARGE DEFORMATION}

Junji FURUKAWA (Department of Synthetic Chemistry, Faculty of Engineering, Kyoto University, Yoshida-cho, Sakyo-ku, Kyoto, 606, Japan), Hiroshi OKAMOTO and Shinji INAGAKI (Department of Applied Chemistry, Aichi Institute of Technology, Yakusa-cho, Ttoyota, 470-03, Japan)

The equation of rubber elasticity proposed by the authors on the basis of the average network chain principle is applicable to explanation of uniaxial stress-strain behavior of rubber vulcanizates at large defor- 
mation for both the extension and the retraction curve of hysteresis cycle. But the plotted line is usually observed to deviate some what from a straight line at the point of small deformation region. The suthors considered this deviation as due to the internal viscosity of rubber vulcanizates and carried out to analyzed this problem molecularly by means of the three element viscoelastic and the pseudo crosslink network model. As a result of the analysis by means of the three element viscoelastic model, the parameter $b$ or $b^{\prime}$ which is introduced in the presented equation as a correction term is recognized as a value depending on the internal viscosity coefficient of vulcanized rubber and the strain rate of deformation. These dependencies were confirmed experimentally.

The correction terms $b$ and $b^{\prime}$ were also recognized experimentally to be proportional with the $C_{2}$ term of the Mooney-Rivlin plot.

Then, the molecular meaning of the $C_{2}$ term became more definite.

These experimental tendencies were also recognized in the case of a higher oil extended SBR vulcanizate. On the other hand, the difference between the values of $b$ and $b^{\prime}$, and thixotropical properties as an example of hysteresis phenomenon cannot be explained by means of the viscoelastic model.

Then, the authors assumed an entanglement of network chain due to the intermolecular force as the secondary crosslink, and analyzed its change kinetically and could successfully explain the hysteresis phenomenon.

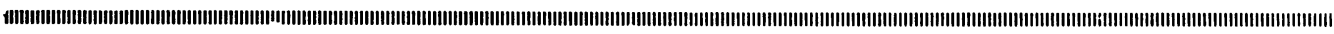

\title{
補強ゴムの延伸特性と形態学的観察
}

\author{
（昭和50年12月 9 日 受理）
}

\section{戸谷 義弘* 寒河江静枝 ${ }^{*}$ 瀬谷 弘旦* 杉 長俊 ${ }^{*}$}

\begin{abstract}
要旨 純ゴム, 炭酸カルシュウム充てん, カーボン・ブラック補強 SBR の二軸延伸破壊特性を研究し た．同時に延伸下の電子顕微鏡観察を行った：二軸延伸下では，破断時のゴム鎖の平均の伸びはゴム相の橋 かけ密度の $(-1 / 2)$ 乗に比例することが認められ，これよりゴム鎖が伸び切った時破壊が起こることを推定 した．二軸延伸下では厚さ $1000 \AA$ の延伸方向に平行な低密度の面状構造が生じることを観察した．この低 密度構造は補強ゴムにおけるエネルギー弾性の発現と関係しているであろう.
\end{abstract}

\section{1. はじめに}

小谷らは, 純ゴム加硫物は, 特定の温度条件下では, ゴム鎖が伸び切ったとき，破断すると報告している1). 川端は，同じく純ゴム加硫物の二軸延伸の実験より，い ずれかの方向への鎖の伸びが限界に達したとき，破壊が 起こると報告している22. したがって，無定形純ゴム加 硫物においては，ゴム網目の構造から決定される限界伸

* 日本ゼオン株式会社 技術開発センター （元210 川崎市川崎区夜光 $1-2-1 ）$
びで破断が起こるのであり，引張強さは二義的なものと 考えてよいと説明されよう。しかしはがら粒子補強ゴム に関してはこのような単純な理論を支持する事実は，ま だ報告されていない.

$\mathrm{Zapp} \mathrm{Guth}^{3)}$ また藤本ら ${ }^{4)}$ は, カーボンブラック(以 下 CB と略記) 補強ゴムの弾性はエネルギー弾性である と報告している.しかしながら，純ゴム加硫物のエント ロピー弾性が, 補強によりエネルギー弾性に変化してい く機構を説明する有効な理論はいまだない. 我々は単純延伸下での電子顕微鏡観察により, $\mathrm{CB}$ 補 